\title{
Peningkatan Kapasitas Masyarakat Kopi di Desa Aik Berik, Kecamatan Batu Kliang Utara, Kabupaten Lombok Tengah
}

\author{
Taslim Sjah ${ }^{1,2 *}$, Halil1,2, Iketut Budastra1,2, I Gusti Lanang Parta Tanaya ${ }^{1,2}$ \\ ${ }^{1}$ Faculty of Agriculture, University of Mataram, Jalan Majapahit 62 Mataram 83125, Indonesia \\ ${ }^{2}$ Study Program of Dryland Resource Management, Postgraduate Study, University of Mataram, Jalan Majapahit 62 Mataram 83125 , \\ Indonesia
}

\section{Article Info}

Received: November 28th, 2020

\begin{abstract}
Abstrak: Kopi Robusta merupakan salah satu tanaman perkebunan penting di Kabupaten Lombok Tengah, dengan salah sentra produksinya berada di Kecamatan Batu Kliang Utara. Kopi tersebut umumnya dijual oleh petani produsen dalam bentuk mentah atau tanpa pengolahan, namun beberapa orang melakukan pengolahan baik secara individual maupun kelompok. Kelompok pengolah kopi telah melakukan pengolahan dan pemasaran kopi yang cukup berhasil ditandai oleh produk olahan mereka yang hampir selalu habis. Namun mereka masih ingin maju, dan ingin memperoleh layanan bimbingan atau penyuluhan terkait berbagai aspek kopi mulai dari aspek produksi, pengolahan, pengembangan usaha, penggunaan teknologi, dan pemasaran, seperti pemasaran online. Selain masalah produksi, mereka menghadapi masalah pemasaran dan manajemen usaha. Untuk mengatasi masalah-masalah tersebut dan sekaligus meningkatkan kondisi kehidupan masyarakat maka dilakukan kegiatan pengabdian ini, yaitu melakukan transfer ilmu pengetahuan tentang peningkatan kapasitas masyarakat (petani) kopi di Desa Aik Berik, Kecamatan Batu Kliang Utara, Kabupaten Lombok Tengah. Tujuan kegiatan ini untuk meningkatkan kemampuan kelompok masyarakat produsen/pengolah kopi dalam hal teknik pemasaran dan manajemen. Evaluasi terhadap kegiatan menunjukkan hasil positif berupa peningkatan pengetahuan dan semangat berusaha karena adanya potensi peningkatan keuntungan yang diperoleh dengan penerapan pengetahuan yang telah diberikan dan pengetahuan sebelumnya. Oleh karena itu kegiatan semacam ini perlu dilakukan lagi di lokasi-lokasi baru maupun pada bidang-bidang kegiatan (bisnis) baru. Kegiatan penyuluhan seperti ini perlu dilakukan karena dibutuhkan oleh masyarakat setempat dan potensi sumberdaya alam dan sumberdaya manusia untuk melakukan kegiatan tersebut cukup besar.
\end{abstract}

Kata Kunci: Kopi; Peningkatan Kapasitas; Pemberdayaan Masyarakat.

Abstract: Robusta Coffee is one of the important plantation crops in Central Lombok Regency, with one of the production centers in Batu Kliang Utara district. The coffee product is generally sold by growers in raw or unprocessed form, but some people do the processing individually or in groups. The coffee processing group has processed and marketed coffee with some success, showed by almost all products sold out. However, they still want to move forward and receive guidance or advice on different aspects of coffee from the aspects of production, processing, business development, the use of technology, marketing such as online marketing. This manufacturing problem is exacerbated by marketing and business management issues. In order to overcome these problems and at the same time to improve the living conditions of the community, this service activity was carried out, namely transferring knowledge about increasing the capacity of the coffee community in Aik Berik Village, Batu Kliang Utara Sub-District, Central Lombok Regency. The aim of this activity is to increase the capacity of coffee processing groups in terms of technical marketing and management. Evaluation of activities showed positive results in the form of increased knowledge and enthusiasm for business due to the potential for increased benefits obtained through the application of the acquired knowledge and previous knowledge. Therefore, these types of activities must be repetitively applicated in new locations and in new (business) activity fields. Awareness activities such as these must be carried out as they are necessary for the local community and the potential for natural and human resources to carry out these activities is quite high.

Keywords: Coffee, capacity building, community development.

Citation: $\quad$ Sjah, T., Halil, H., Budastra, I.K., Tanaya. I.G.L.P. (2020). Peningkatan Kapasitas Masyarakat Kopi di Desa Aik Berik, Kecamatan Batu Kliang Utara, Kabupaten Lombok Tengah. Unram Journal of Community Service 1(1), 1-5. 


\section{Pendahuluan}

Pembangunan pertanian di Indonesia berlangsung secara terus-menerus dengan tujuan meningkatkan produksi pertanian dan pendapatan pelakunya, yang pada jangka panjang diharapkan mampu meningkatkan kondisi perekonomian Indonesia secara umum (Menteri Pertanian RI, 2015; Minister of Agriculture, 2014). Berbagai upaya dilakukan untuk membangun pertanian, antara lain saat ini dilakukan dengan pendekatan agrowisata (Utama, 2012) dan agribisnis (Saragih, 2004).

Pendekatan agribisnis saat ini semakin mengemuka karena adanya 'nilai' dari produk atau kegiatan yang dilakukan. Secara khusus, hal ini diimplementasikan melalui peningkatan kegiatan pengolahan hasil pertanian dan selanjutnya pemasarannya (Asriani, 2003; Research Center for Socio-Economic, 1996; Saragih, 2004; Soekartawi, 1991). Hasil pertanian direkomendasikan untuk dipasarkan dalam bentuk yang sudah diolah karena pemasaran dalam bentuk ini memberikan nilai tambah bagi para pelakunya melalui penciptaan kegunaan bentuk, waktu, dan tempat (Dunne, 1999; Kotler \& Armstrong, 2011; Sjah, 2010; Stanton, Etzel, \& Walker, 2000).

Salah satu hasil pertanian Kabupaten Lombok Tengah adalah kopi. Produksi ini umumnya dijual oleh petani produsen dalam bentuk mentah dan sudah ada pula yang diolah serta dijual dalam bentuk kemasan yang menarik. Dari hasil survei pendahuluan ke lokasi produksi kopi diperoleh informasi bahwa kopi mentah tersebut dijual dalam bentuk yang telah disortasi dan juga tanpa sortasi. Demikian juga produk olahan kopi, seperti kopi bubuk, merupakan kopi bubuk murni untuk kualitas terbaik, dan ada pula yang dicampur dengan bahan lain seperti beras dan rempahrempah, dan ini semua disesuaikan dengan permintaan konsumen atau pembeli. Harga jual produk berbeda antara produk yang disortasi dan tidak disortasi. Kopi bubuk yang dijual oleh masyarakat setempat adalah dalam kemasan plastik yang menarik, disertai dengan gambar yang mengundang selera untuk mencobanya. Gambaran ini menampakkan tidak ada masalah dengan bisnis kopi di daerah setempat. Namun terungkap juga keinginan petani kopi, pengolah kopi, dan pedagang kopi untuk menambah pengetahuan mereka dalam beberapa hal. Hal ini menunjukkan bahwa mereka mempunyai beberapa masalah yang sangat mereka rasakan sendiri. Masalah yang disampaikan dan diinginkan solusinya antara lain sebagai berikut:

1. Aspek produksi, seperti cara penyambungan dan produksi kopi yang lebih produktif, produksi kopi organik, dan peningkatan kekhasan kopi setempat.
2. Aspek pengolahan, seperti penggunaan mesinmesin pengolah kopi. Secara kebetulan ada mesin pengolah bantuan bagi masyarakt setempat, tetapi saat ini tidak berfungsi atau dikatakan macet.

3. Pengembangan usaha, pemasaran, dan penggunaan teknologi, seperti pemasaran online. Masyarakat sering mendengar tentang pemasaran menggunakan teknologi online. Mereka ingin menggunakannya, tapi di lokasi tersebut masih terkendala dengan sinyal yang tidak menjangkau.

4. Ketiga hal yang diatas antara lain disebabkan oleh masih kurangnya kemampuan manajemen usaha oleh masyarakat kopi baik petani maupun pengolah kopi.

Secara ringkas semua masalah diatas dapat dirangkum menjadi masalah produksi, pemasaran, manajemen usaha, dan penggunaan teknologi. Untuk mengatasi masalah-masalah tersebut dan sekaligus meningkatkan kondisi kehidupan masyarakat maka dilakukan kegiatan pengabdian ini, yaitu melakukan transfer ilmu pengetahuan tentang peningkatan kapasitas masyarakat kopi di Desa Aik Berik, Kecamatan Batu Kliang Utara, Kabupaten Lombok Tengah.

Tujuan kegiatan ini secara umum adalah untuk meningkatkan pendapatan masyarakat kopi, khususnya petani di Desa Aik Berik, Kecamatan Batu Kliang Utara, Kabupaten Lombok Tengah, dengan meningkatkan kemampuan mereka dalam melakukan kegiatan bisnis kopi yang mereka usahatanikan. Kegiatan ini diharapkan bermanfaat bagi petani kopi dan pelaku usaha terkait lainnya di wilayah tersebut, dalam meningkatkan pengetahuan dan keterampilan teknis dan manajemen dalam melakukan kegiatan usahtani kopi dan bisnis lanjutannya. Dari peningkatan yang terjadi diharapkan ada perbaikan tingkat perekonomian pelaku. Juga diharapkan bahwa dari kegiatan in Pemerintah Daerah dapat memperoleh manfaat dalam bentuk pengurangan pengangguran perdesaan dan pencipataan lapangan kerja, serta memperoleh kontribusi dari kegiatan bisnis kopi yang dilakukan di wilayah tersebut.

\section{Metode Pelaksanaan}

Kegiatan pengabdian ini dilakukan di Desa Aik Berik, Kecamatan Batu Kliang Utara Kabupaten Lombok Tengah. Desa ini dan sekitarnya merupakan daerah hutan dan merupakan daerah wisata alam. Tanaman kopi merupakan salah satu tanaman yang tumbuh subur di daerah ini. Sasaran dari kegiatan pengabdian ini adalah petani dan anggota keluarganya di kawasan tersebut. Petani dan anggota keluarga petani diharapkan dapat melakukan usahanya secara terpadu dalam pendekatan sistem agribisnis, dan 
dilakukan secara efisien dan efektif, sehingga dapat memberikan kontribusi pada peningkatan pendapatan rumah tangga petani.

Adapun tahapan kegiatan pengabdian pada masyarakat yang dilakukan adalah berikut:

1. Tahap persiapan: Survei pendahuluan untuk mengidentifikasi persoalan yang terkait dengan pelaksanaan bisnis budidaya kopi dan pengolahan kopi di lokasi pengabdian.

2. Tahap pelaksanaan kegiatan: Kegiatan yang dilakukan adalah penyuluhan, praktek/demontrasi dan pembinaan langsung oleh tim pelaksana kegiatan. Tahapan kegiatan untuk mencapai tujuan umum tersebut dilakukan melalui tujuan-tujuan khusus untuk meningkatan kemampuan teknis dan manajemen dalam hal-hal sebagai berikut:

a. Manajemen produksi (Beierlein, Schneeberger, \& Osburn, 1986; Downey \& Erickson, 1987)

b. Pengetahuan dan teknologi budidaya (Ranasinghe, 1997)

c. Pengetahuan dan teknologi panen, pasca panen, dan pengolahan hasil (Zainuri, Handayani, Werdiningsih, \& Widyasari, 2017)

d. Pemasaran produk (Down \& Kotler, 2011; Smith, 2002; Ruskin-Brown, 1999; Beierlein, 1986; Covello \& Hazelgren, 2004; Sjah, Rosmilawati, \& Zainuri, 2012).

e. Manajemen usaha (Beierlein et al., 1986; Sjah, 2012; Covello \& Hazelgren, 2004; Downey \& Erickson, 1987).

f. Lain-lain yang terkait.

Tahap evaluasi: dilakukan sebagai peningkatan kualitas kegiatan pengabdian selanjutnya.

\section{Hasil dan Pembahasan}

\section{Realisasi kegiatan}

Kegiatan ini dilaksanakan untuk mencapai tujuan yang telah disebutkan pada bagian tujuan kegiatan ini. Materi yang diberikan untuk penambahan pengetahuan dan/atau keterampilan adalah sesuai dengan tujuan dan materi kegiatan yang telah ditetapkan.

Kegiatan dilaksanakan pada tanggal 18 November 2020 di Desa Aik Berik, Kecamatan Batu Kliang Utara, Kabupaten Lombok Tengah. Kegiatan dilakukan di salah satu ruangan milik salah satu anggota kelompok pengolah kopi (Kelompok Usaha Bersama KUB Benang Stokel, Desa Aik Berik, Kecamatan Batu Kliang Utara. Peserta pelatihan terdiri atas bapak-bapak tani dan ibu-ibu tani/pengolah hasil kopi.

Materi penyuluhan adalah seperti telah dirincikan pada bagian pelaksanaan kegiatan, yaitu meliputi: Pemilihan jenis tanaman; Manajemen produksi; Pengetahuan dan teknologi budidaya; Pengetahuan dan teknologi panen, pasca panen, dan pengolahan hasil; Pemasaran produk; Manajemen usaha; dan lain-lain yang terkait. Materi penyuluhan disampaikan secara ceramah dan diikuti dengan diskusi.

\section{Pelaksanaan}

Jumlah peserta dibatasi hingga 10 orang saja untuk mendapatkan efektivitas kegiatan dan juga mempertimbang peserta yang terlibat dengan kegiatan perkopian saja. Namun dapat dikatakan bahwa masyarakat Desa Aik Berik, Kecamatan Batu Kliang Utara mempunyai kegiatan yang beragam, tetapi pelaku kegiatan beragam tersebut bergabung dalam kelompok-kelompok yang sama, seperti Kelompok Usaha Bersama (KUB) atau Kelompok Wanita Tani (KWT). Penyuluhan dilakukan secara lisan tanpa alat bantu berenergi listrik, seperti LCD atau komputer.

Metode yang digunakan dalam pelatihan ini adalah metode ceramah dan diskusi. Setelah menyampaikan maksud pertemuan, tim pengabdian melakukan penyampaian materi dengan melalui cermah. Setelah ceramah maka dilanjutkan dengan diskusi, dan peserta diberikan kesempatan juga untuk bertanya saat penjelasan disampaikan. Bahkan, tim pelaksana sendiri memberikan pancingan-pancingan pertanyaan dalam penyampaian materi penyuluhan. Pertanyaan diajukan oleh para peserta dan tim penyuluh menjawab pertanyaan secara bergiliran sesuai dengan keahlian atau materi yang disampaikan. Kegiatan ini berlangsung dari pukul 10.00 sampai 12.30 .

\section{Evaluasi kegiatan}

Kegiatan telah dilaksanakan sesuai dengan rencana, termasuk tentang materi, waktu, dan hasil yang diharapkan. Dengan kata lain, pelaksanaan kegiatan ini dinilai efektif. Efektivitas hasil diperkuat dengan komunikasi yang baik, interaktif, dan berkelanjutan selama pelatihan dan setelah selesainya kegiatan penyuluhan ini. Peserta pelatihan menanyakan banyak hal kepada narasumber dan mereka antusias. Tim penyuluh juga sangat bersimpati terhadap kesulitan yang sedang dialami oleh peserta penyuluhan, yang sebagian masih merasakan kesedihan dan shock karena kejadian gempa yang berulang-ulng di lokasi tersebut dan dengan skala gempa yang relatif besar dan telah berdampak merusak bangunan, bahkan lahan. Beberapa peserta menyatakan bahwa mereka akan memanfaatkan materi pelatihan untuk dipraktikkan. Peserta juga berhasrat untuk mendapatkan pelatihan tambahan dan bimbingan lanjutan dalam beberapa aspek, antara lain aspek kehidupan tanaman dan bisnisnya, agar manfaat 
kegiatan dapat dirasakan. Mereka menyampaikan keinginan untuk dikunjungi kembali di waktu-waktu mendatang dengan pengetahuan dan teknologi baru untuk mereka.

\section{Faktor pendukung dan penghambat kegiatan}

Ada cukup banyak faktor yang mendukung pelaksanaan kegiatan penyuluhan ini dan pelaksanaan hasil-hasilnya. Termasuk sebagai faktor pendukung ini adalah antusiasme dan kesadaran peserta untuk meningkatkan kondisi perekonomian mereka. Faktor ini menggerakkan mereka (petani dan keluarga) untuk mengikuti kegiatan penyuluhan dan kemudian mengaplikasikan pemgetahuan yang didapat.

Selain itu, masyarakat desa setempat merupakan masyarakat yang suka bekerjasama untuk kepentingan bersama (bergotong royong merupakan tradisi yang rajin dipraktikan). Kondisi ini merupakan modal untuk maju bersama dalam suatu bisnis, termasuk bisnis yang bisa dikelola secara kelompok, ataupun secara individual.

Sebaliknya ada juga faktor penghambat seperti jarak lokasi yang cukup jauh sehingga agak menyulitkan untuk bisa sering-sering bertemu dengan anggota kelompok masyarakat lainnya. Demikian juga dengan jauhnya desa ini dengan pusat-pusat ekonomi sehingga untuk pemasaran produk akan memerlukan transportasi yang jauh dan biaya yang relatif tinggi. Satu hal lagi yang menjadi hambatan adalah jangkauan jaringan telpon seluler yang tidak bisa terus menerus lancar di lokasi tersebut. Mereka ingin ada jaringan untuk komunikasi dalam jaringan (online), yang banyak manfaanya seperti melakukan pemasaran dan komunikasi secara onine. Oleh karena itu, faktor-faktor yang menghambat ini perlu dipikirkan pemecahannya, antara lain dengan membangun jaringan komunikasi tersebut. Banyak pihak perlu bekerjasama untuk mengatasi masalah ini.

\section{Kesimpulan}

Evaluasi terhadap kegiatan menunjukkan hasil positif berupa peningkatan pengetahuan dan semangat berusaha karena adanya potensi peningkatan keuntungan yang diperoleh dengan penerapan pengetahuan yang telah diberikan dan pengetahuan sebelumnya. Oleh karena itu kegiatan semacam ini perlu dilakukan lagi di lokasi-lokasi baru maupun pada bidang-bidang kegiatan (bisnis) baru. Kegiatan penyuluhan seperti ini perlu dilakukan karena dibutuhkan oleh masyarakat setempat dan potensi sumberdaya alam dan sumberdaya manusia untuk melakukan kegiatan tersebut cukup besar.

\section{Ucapan Terima Kasih}

Terima kasih disampaikan kepada semua pihak yang telah membantu terselenggaranya kegiatan ini, dalam urusan pendanaan, pelaksanaan, dan administrasi dari kegiatan ini. Secara khusus, terimaksih disampaikan kepada Universitas Mataram yang mendanai kegiatan ini.

\section{Daftar Pustaka}

Ahyari, A. 1996. Manajemen Produksi: Perencanaan Sistem Produksi. Yogyakarta: BPFE.

Asriani, P. S. 2003. Konsep agribisnis dan pembangunan pertanian berkelanjutan di Indonesia. Agrisep, 1(2): 144-150.

Badan Litbang Pertanian RI. 2017. Kawasan Rumah Pangan Lestari Jakarta: Kementerian Pertanian Republik Indonesia.

Beierlein, J. G., Schneeberger, K. C., \& Osburn, D. D. 1986. Principles of Agribusiness Management. Englewood Cliffs, New Jersey: Prentice-Hall.

Covello, J. A., \& Hazelgren, B. J. 2004. Rencana Bisnis Lengkap (The complete book of business plans). Batam: Interaksara.

Downey, W. D., \& Erickson, S. P. 1987. Agribusiness Management. New York: McGraw-Hill.

Dunne, T. 1999. Marketing agricultural products: An Australian perspective. South Melbourne: Oxford University Press.

Kotler, P. 1997. Manajemen Pemasaran: Analisis, Perencanaan, Implementasi, dan Kontrol (H. Teguh, \& R. A. Rusli, Trans.) (9 ed.). Jakarta: Prenhallindo.

Kotler, P., \& Armstrong, G. 2011. Principles of Marketing (14 ed.). New Jersey: Pearson Prentice Hall.

Menteri Pertanian RI. 2015. Rencana Strategis Kementerian Pertanian Tahun 2015-2019 Jakarta: Ministry of Agriculture.

Minister of Agriculture. 2014. Kebijakan Pembangunan Pertanian 2015-2019 (Agricultural Development Policy 2015-2019). Jakarta: Ministry of Agriculture.

Ranasinghe, T. T. 1997. Civil agronomy: A new dimension of agricultural extension to invoke poverty issues for sustainable rural development. International Journal of Sustainable Development and World Ecology, 4(2): 112-122.

Research Center for Socio-Economic. 1996. Konsep dasar pengkajian dan pengembangan sistim usahatani berorientasi agribisnis (A basic concept of assessment and development of 
farming systems with agribusiness orientation). Bogor: Research Center for Socio-Economic.

Saragih, B. 2004. Pembangunan pertanian dengan paradigma sistem dan usaha agribisnis. Jakarta.

Sjah, T. 2010. Ekonomi Pertanian. Mataram: Mataram University Press.

Sjah, T., Rosmilawati, \& Zainuri. 2012. Rencana Bisnis: Untuk pengusaha kecil dan pemula dalam usaha pengolahan hasil pertanian. Mataram: Mataram University Press.

Soekartawi. 1991. Agribisnis Teori dan Aplikasi. Jakarta: Rajawali Press.

Stanton, W. J., Etzel, M. J., \& Walker, B. J. 2000. Fundamentals of Marketing. New York: McGraw-Hill.

Swastha, B., \& Irawan. 2005. Menejemen Pemasaran Modern (2 ed.). Yogyakarta: Liberty.

Tohir. 2017. Manajemen Usaha, Wikipedia, Vol. 2017.

Utama, I. G. B. R. 2012. Agrowisata Sebagai Pariwisata Alternatif di Indonesia. Denpasar: Universitas Udayana.

Zainuri, Handayani, B. R., Werdiningsih, W., \& Widyasari, W. 2017. Modul pelatihan pengolahan hasil pertanian untuk meningkatkan ekonomi perempuan di Kabupaten Lombok Utara. Mataram: Konsorsium Karya TerpaduMCAI. 